ROCZNIKI KULTUROZNAWCZE

Tom X, numer 3 - 2019

DOI: http://dx.doi.org/10.18290/rkult.2019.10.3-2

MAŁGORZATA GRUCHOŁA

\title{
THE MACHINE IN THE BODY - THE BODY IN THE MACHINE: PERCEPTION OF THE HUMAN BODY IN A POST-BIOLOGICAL SOCIETY
}

\section{INTRODUCTION}

Nowadays, we witness the emergence of a new type of individual/person: homo machina (machinised man, machine-man). '[He: MG] is a symbol of a strong link between the individual and electronic systems and devices and is a reflection of their influence on the original form of man. From this perspective, modern engineering and technology not only endow a human being externally with appendages but they also influence the inside of a human being. ${ }^{1}$ The hybrid form of a human and a machine which is the closest to the human being are cyborgs. In 1960 Manfred Clynes and Nathan Kline published the article Cyborgs and Space, in which they characterised the cyborg as a 'self-regulating man-machine system.' The system incorporates exogenous components extending the self-regulatory control and homeostasis of the organism in order to adapt it to new environments [connected with the future exploration of space]'. ${ }^{2}$ It should be stressed that the term is used only to those people whose nervous system is connected with electronic elements and mechanical devices by means of an invasive method. What is more, the computer

Dr hab. MaŁgORZATa GruchoŁa, prof. KUL - Department of Visual Communication and New Media Institute of Journalism and Management, Faculty of Social Sciences of The John Paul II Catholic University of Lublin, correspondence address: Al. Racławickie 14, 20-950 Lublin; e-mail: mgruch@kul.pl; ORCID: https://orcid.org/0000-0002-2367-0416.

${ }^{1}$ Edyta Kilian, "Roman Bromboszcz jako poeta-cyborg. Narzędzia i techniki współczesnego twórcy," in Technokultura: transhumanizm i sztuka cyfrowa, ed. Damian Gałuszka, Grzegorz Ptaszek, Dorota Żuchowska-Skiba (Kraków: Wydawnictwo Libron, 2016), 217.

2 Manfred E. CLYNES \& Nathan KLINE, “Cyborgs and Space,” Astronautics no. 8(1960): 32, https:// pl.scribd.com/doc/2962194/Cyborgs-and-Space-Clynes-Kline?autodown=pdf (accessed: 3.10.2019). 
and the nervous system should influence each other. ${ }^{3}$ The cyborg is the result of cyborgization, that is a process in which a human being or another organism enters an immersive symbiosis with technologies/machines. Thus, the process of cyborgization is interweaving advancements in technology with human evolution which aims to improve human abilities, ${ }^{4}$ an intentional integration of human life with the advancements of technology. ${ }^{5}$

Science fiction literature ${ }^{6}$ provides us with descriptions of many types of such beings, two types are most common, though, as David Tomas says. They are: a machine in the human body or a human being inside a machine. The former means a human body, natural or obtained through genetic engineering which, however, contains mechanical or electronic brain implants, prosthesis and transplanted organs. With respect to the latter, a cyborg does not have an organic form but a human mind, or rather a computerised recording of human consciousness introduced into the memory of the machine. Other types, such as: a robot and an android, or gynoid (the female form), are extra-human forms. It should be noted that although they can look just like people, they are only artificially manufactured robots, organic creations - effects of nanotechnology, robotics, automation or other innovative technologies. They never combine the organic with the non-organic. ${ }^{7}$ Therefore, in this article I pass over issues connected with extra-human forms (a humanoid robot, an android, a gynoid), and I limit myself to a critical analysis of a new type of person: a cyborg - a hybrid of a human being and a machine in a post-biological society.

Questions concerning the nature of a human being and humanity in a postbiological society dominated by the development of advanced technologies, both with respect to research into the creation of new organisms, genome, or cloning, but also digital media technologies, fall within the current of questions about the body-machine relationship. How does contemporary science, above all biotechnology, influence the human body? How does it perceive and shape it?

\footnotetext{
${ }^{3}$ Ibidem.

${ }^{4}$ Emma PALESE, "Robots and cyborgs: to be or to have a body?" Poiesis \& Praxi 8, no. 4(2012): 191-196.

${ }^{5}$ Shigeru MUSHIAKI, "Neuroscience and nanotechnologies in Japan-beyond the hope and hype of converging technologies," International Journal of Bioethics 22, no. 1(2011): 91-97.

${ }^{6}$ Technokultura: transhumanizm i sztuka cyfrowa, ed. Damian Gałuszka, Grzegorz Ptaszek, Dorota Żuchowska-Skiba (Kraków: Wydawnictwo Libron, 2016).

${ }^{7}$ Monika BAKKe, Cialo otwarte: filozoficzne reinterpretacje kulturowych wizji cielesności (Poznań: Wydawnictwo Naukowe UAM, 2000), 163.
} 
In of Dinna Haraway's, opinion - the way we imagine human-technological hybrids is closely connected with ways of organising social life mediated by highly-advanced technologies. Machines of the late 20th century completely blurred the boundary between what is natural and artificial, the mind and the body, self-development and external intervention, as well as many other dichotomies which were used to describe organisms and machines. A cyborg, according to D. Haraway, challenges ontological purity by questioning the existence of boundaries between what is human and animal, organic and non-organic, as well as the boundaries separating the body and the machine. ${ }^{8}$ The post-biological society is the result of a post-biological evolution, which has transitioned from a biological paradigm, driven by the propagation of genes, to a nonbiological (e.g., cultural or technological) paradigm, presumably driven by some alternative replicator (e.g., memes or temes), and potentially resulting in the extinction, obsolescence, or trophic reorganization of the former. ${ }^{9}$ A post-biological society is characterized by applying the convergence of nanotechnology, biotechnology, information technology, automation, robotics, cognitive science and artificial intelligence in order to improve the efficiency of man. ${ }^{10}$

In the age of a post-biological society, dominated by the development of advanced technologies, both with respect to research into creating new organisms, genome or cloning, but also digital media technologies, we are entering the age of posthumanism. Posthumanism is often defined as post-humanism and post-anthropocentrism, ${ }^{11}$ it is 'post' with respect to the concepts of the human and to historical signs of humanism, both based on the premises of a hierarchical social construct and the central position of humans. In a postbiological society, the human body becomes a body to be manufactured, complemented and supplemented. 'I am condemned-Andrzej Falkiewicz notices - to use the matter of the outside world to complement myself. First, I find that my body is non-independent - so it must be supplemented, complemented by other bodies. Clothes which protect me from the cold are such

\footnotetext{
${ }^{8}$ Donna HARAwAY, "A cyborg manifesto: Science, technology, and socialist-feminism in the late twentieth century," in Simians, cyborgs and women: The reinvention of nature (New York: Routledge, 1991), 151.

${ }^{9}$ Hans Moravec, Mind Children: The Future of Robot and Human Intelligence (Cambridge, Mass: Harvard University Press, 1988).

${ }^{10}$ Mihail C. Roco \& William S. BAINBRIDGE, "Overview Converging Technologies for Improving Human Performance," in Converging Technologies for Improving Human Performance, ed. Mihail C. Roco \& William S. Bainbridge (Dordrecht: Kluwer Academic Publishers (currently Springer) 2004), 1-27.

${ }^{11}$ Rosi BraidotTI, The Posthuman (Oxford: Polity Press, 2013).
} 
a body, as are tools used for manufacture and protection - as are 'beautiful' attires and 'invaluable' object of worship which are augmented by my 'elegant' gestures and 'proper' conduct. ${ }^{12}$ Developing A. Falkiewicza's thoughts, we should also note that the body may often be complemented with other foreign bodies, more and more often also with machines, most often cybernetic ones. Machines which can fit into the human body (e.g. prosthesis, implants), electrodes, microchips, but also through a body inside a machine by transferring the mind into another medium or the internet of things. The body of the contemporary human can be perceived as 'material' to be manufactured, '[...] so that it fits individual and social notions, corresponds to the determined plan of self-creation, whose algorithms are provided at least in selected cases by culture' Agnieszka Ogonowska notes. ${ }^{13}$

To systematise terminology, we should note-after Łukasz Sarowskithat until the middle of the 20th century, all available tools could be classified into four types of machines: motor-driven, working, technological and transport ones. Technological progress resulted in the necessity to expand the term 'machine' to include mechanized devices. Iwan Artobolewski developed a new, suggested version of the definition. In his opinion, a machine is 'an artificial device designed to partially or fully substitute energetic, physiological and intellectual functions of a human being. ${ }^{14}$ This type of devices are called cybernetic machines. They include systems imitating biological and physiological processes which are present in animate nature. ${ }^{15}$ Therefore, in this article I limit the understanding of the term 'machine' to the cybernetic machine.

The aim of the article is to provide a critical analysis of the body-machine relationship in the context of a post-biological society from two perspectives: on the one hand, the functioning of a machine inside a body, as an expression of transgression, on the other one - the functioning of a body in a machine, as a challenge and a premise of transhumanism. It should be noted that both transgression and transhumanism can be an impulse for change. Therefore, on the one hand technology can be a manifestation of transgression, that is crossing

\footnotetext{
${ }^{12}$ Agnieszka OgOnOwSKA, "Ubiór jednostki jako przedmiot interpretacji i badań interdyscyplinarnych," in Komunikacja wizualna, ed. Piotr Francuz (Warszawa: Wydawnictwo Naukowe Scholar, 2012), 239.

${ }^{13}$ Ibidem, 241.

${ }^{14}$ Józef KNAPCZYK, Zarys robotyki (Nowy Sącz: Wydawnictwo Naukowe Państwowej Wyższej Szkoły Zawodowej w Nowym Sączu, 2015), 10.

${ }^{15}$ Lukasz SAROwSKI, "Robot społeczny - wprowadzenie do zagadnienia," Roczniki Kulturoznawcze 8, no. 1(2017): 75-78.
} 
the boundaries of our own possibilities, achievements and limitations and, on the other one, an expression of transhumanism, that is crossing the boundaries of human limitations arising from the human nature.

Placing the body within the scope of the above-described issues, we should ask:

- what image of the body is suggested, imposed or maybe even enforced by a post-biological society?

- how does the body function and influence the machine (a body in a machine), how does the machine influence the body (a machine in a body) and finally-how do these relationships fit into the broader social context?

- are the attempts made within hybridization and transhumanism going in the direction of the internet of bodies?

- can an internet of bodies be developed in a similar fashion to the internet of things?

When making decisions concerning issues expressed in the title of this article, I assumed that crossing subsequent boundaries of the human body in a post-biological society changes the body-machine relationship. This is an analytical-descriptive article.

\section{THE HUMAN BODY IN A POST-BIOLOGICAL SOCIETY}

A dynamic development of innovative technologies, progress of cyborgisation, research into artificial intelligence and embodiment of information systems ${ }^{16}$ contribute to an intensive development of the post-biological society. ${ }^{17}$ It should be noted that although Roy Ascott uses the term, it does not give its exact understanding. In the collective book Consciousness reframed: Art and consciousness in the post-biological era, under his own editors he does not explain what this postbiological era is. We can only find out from the context.

\footnotetext{
${ }^{16}$ An example of research into the embodiment of information systems are studies of Hiroshi Ishiguro, who built his 'robotized lookalike.'

${ }^{17}$ Roy AsCOTT, "Behaviourables and Futuribles," in Theories and Documents of Contemporary Art: A Sourcebook of Artists' Writings, ed. Kristine Stiles, Peter Howard Selz (Berkely and Los Angeles, CA: University of California Press, 1996), 489-491; Prof. Roy Ascott (Great Britain), http://www. poznan.pl/mim/main/prof-roy-ascott-wielka-brytania,p,12973,23787,23930.html (accessed: 7.10.2019). R. Ascott is one modern theoreticians of the media, biotechnology and information theory as well as a pioneer of telematic art. He engages in extensive studies into the possibilities of communication, he deals with ethics of scientific research conducted with the use of state of the art technology (technoethics and bioethics). He is the author of numerous pioneering and innovative academic programmes on combining modern design with scientific achievements, including biotechnology, information theory, consciousness and perception.
} 
In the introduction to the thematic issue of the magazine Computers \& PostBiological Art, he explains: "The conference was convened to bring into Downloaded by o focus developments in this new, emergent field, employing the term post-biological to cover all aspects of life which are mediated, extended or transformed by technology, including the mind and consciousness. Of central interest was the impact on art of digital media, bio technology and artificial life, as well as the value of art in understanding cognitive processes, conceptual modelling and theories of mind. We sought to enable ideas from a variety of sources to surface, to be exchanged and developed in ways which might further our individual practice and research." ${ }^{18}$ In another publication he wrote: „Post-biological technologies enable us to become directly involved in our own transformation, and are bringing about a qualitative change in our being. The emergent faculty of cyberception, our artificially enhanced interactions of perception and cognition, involves the transpersonal technology of global networks and cybermedia. We are learning to see afresh the processes of emergence in nature, the planetary mediaflow, while at the same time rethinking possibilities for the architecture of new worlds. Cyberception not only implies a new body and a new consciousness but a redefinition of how we might live together in the interspace between the virtual and the real." 19

In a post-biological society, the human body is perceived as the original prosthesis, which people have learnt to use, hence 'extending the body with the help of other prostheses constitutes only a continuation of a long-term process, which resulted in the formation of a new object as a set of heterogenetic components. ${ }^{20}$ The above-cited original prosthesis (the human body) becomes a subject of integration, improvement, correction but also of some deconstruction. It should be added that the idea of the source prosthesis was developed in the context of technology by Bernard Stiegler after Jacques Derrida. ${ }^{21}$

Disturbances in the perception of the physical form as a domain of nature, within which the body constitutes a closed system with non-changeable elements, are also brought about by medicine through transplants, organ grafts, plastic surgery, regenerative medicine and implantation. This constant confrontation of the body with brand new technologies also raises the question of

18 Roy Ascott, "Consciousness reframed: Art and consciousness in the post-biological era," Digital Creativity 9, no. 1(1998): Computers \& Post-Biological Art: 5-6.

${ }^{19}$ Roy AsCOTT, The architecture of cyberception (Stambut: Leonardo Electronic Almanac, 1994), 3.

${ }^{20}$ Izabela FrAnCKIEWICZ-OLCZAK, "Body art — ciało, sztuka, technologia. Od ciała ułomnego do bezawaryjnego humanoida," Przegląd Socjologii Jakościowej 8, no. 2(2012): 237.

${ }^{21}$ Jacques DERRIDA, "Jednojęzyczność innego, czyli proteza oryginalna," trans. Andrzej Siemek, Literatura na Świecie no. 11-12(328-329)(1998): 24-111. 
the boundaries between the artificial and the natural-Monika Bakke stresses. Donna Harway considers this opposition to be the key one. This is also supported by Claudia Springer, who concludes: 'When the boundary between the human and the artificial disappears, all other dualisms will also disappear, and both their part will become indistinguishable, removing humans from the unique and privileged position which they occupied in the Enlightenment philosophy. In fact, boundaries which undergo transgression are a principal feature of postmodernism, and the cyborg is the ultimate transgression of the boundary.' 22

But this is not the end. Another boundary has been crossed: the one between the sacred and the profane. The inviolability of the body places it within the sacred. Contemporary society, putting aside the concept of the body in personalism and in classical philosophy, transfers it to the sphere of the profane, enabling but also allowing its denaturalization, secularization and mechanization. ${ }^{23}$ Innovative technologies deprive the body of its mysteries-Izabela Franckiewicz-Olczak notes. First of all, the human body is more and more often treated as a 'fabric,' disposable and meaningless raw material. Specialists manipulate the natural body, shape its artificial forms, man-machine hybrids, while robotmachines more and more often imitate human functions and activities. ${ }^{24}$ In the context of the issues suggested by the title we look at the crisis of the understanding of the human being, the undermining of the transcendent dignity of people and the negation of the superiority of the human being.

The blurring of the boundaries of the body and the crisis of the understanding of the human being favours further unification of the body with technology, typical of a post-biological society of the 21 st century. The original prosthesis (the human body) more and more often can be found inside a machine. But also the other way round, the aforementioned new thing can be a machine inside the human body. Nowadays, two philosophical schools exist explaining the potential mechanization of humans. The first one, based on the experience of cyborgisation, opts for transferring the machine into the human body while the other one-the human into the machine through the transfer of the mind into another medium.

\footnotetext{
${ }^{22}$ BAKKe, Ciało otwarte, 55; Claudia Springer, Electronic Eros. Bodies and Desire in the Postindustrial Age (Austin: University of Texas Press, 1996), 34.

${ }^{23}$ FranCKIEWICZ-OlCZAK, "Body art—ciało," 234.

${ }^{24}$ Ibidem, 229.
} 


\section{FUNCTIONING OF THE MACHINE IN THE BODY \\ AS A MANIFESTATION OF TRANSGRESSION}

Leaving aside a detailed terminological analysis of the term 'transgression, ${ }^{25}$ as it is not the main problem of this study, I accept after Józef Kozielecki that transgression is 'an activity - creative, innovative and expansiveboth individually and collectively, which crosses the hitherto boundaries of human material, symbolic, social and cultural achievements. By performing them, man goes beyond his limited possibilities, beyond his imperfection, beyond his finiteness and thanks to this creates new values and realizes new interests. ${ }^{26}$ One of its essential manifestations are the cyborg and the process of cyborgisation. A cyborg is a cybernetic organism whose life functions are carried out or assisted by technical devices. There are many definitions of cyborgs and one of them considers the cyborg as a combination of a human with a machine, it should be stressed that the term is applied only to the people whose nervous system is connected with electronic elements and mechanical devices through an invasive method. What is more, the computer and the nervous system should interact with each other. ${ }^{27}$

Nowadays we are entering the age of the cyborg: a hybrid of a cybernetic machine and a biological organism. ${ }^{28}$ A cyborg, according to Maciej Starkowski is ,a McLuhan's 'man extended by a transmitter"” and Baudrillard's "never-ending series of prostheses," is a man who "externalised" his extensions, made them part of the functioning of the organism and together with the progressing "implantation" allowed technology to penetrate inside his body. ${ }^{29}$ More and more people have artificial organs. In 2018 thirty thousand patients with Parkinons disease had brain implants. Miniaturised technology has more and more influence on human life. Progress in nanotechnology, functioning at the atomic level, promises the replacement of organs which are essential for life in fifteen, and blood cells in twenty years. Futulologists predict that in twenty-five years it will be possible to re-programme the biological structure

\footnotetext{
${ }^{25}$ Małgorzata GRUCHOŁA, “'Wearable technology' wyznacznikiem transgresji czy regresu intelektualno-kulturowego? (na przykładzie transhumanizmu)," Społeczeństwo i Rodzina 55, no. 2 (2018): 50-65.

${ }^{26}$ Józef KozIELECKI, Społeczeństwo transgresyjne. Szansa i ryzyko (Warszawa: Wydawnictwo Akademickie „Żak”, 2004), 45.

${ }^{27}$ Clynes, Kline, "Cyborgs and Space," 32.

${ }^{28}$ Maciej StARKowski, “Technicyzacja ciała. Pytanie o człowieka,” in Umyst-Ciało-Sieć, ed. Edyta Stawowczyk-Tsalawoura, Wojciech Chyła (Poznań: Wydawnictwo Naukowe UAM, 2005), 129.

${ }^{29}$ Ibidem.
} 
people in such a way that the ageing of the organism and of the body can be prevented. ${ }^{30}$

The authors of many pioneering and innovative solutions concerning the problem of the human body in the context of technology, interfaces connecting the man with the machine are French contemporary artist: Orlan and Australian artist Stelarc (or Stelios Arcadiou). Orlan is known as a pioneer of carnal art, a form of self-portraiture that utilizes body modification to distort one's appearance. From 1990, she implemented the project The reincarnation of St Orlan. The project was a series of performance shows during which Orlan's face underwent a metamorphosis using plastic surgery. The artist turned her body into sculptural material. Until now, it was the only one that made plastic surgery a means of artistic expression. Each operation was photographed, and since 1993 broadcast and broadcast live performance could be seen in art

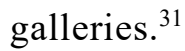

Similarly, Stelarc for years he has been experimenting with technological extensions of his body. His most famous works include a series of performances Suspensions ${ }^{32}$ and Stomach Sculpture. The Sculpture was exhibited as an object in-itself with the accompanying internal video at the NGV, Melbourne 1993. She was not for a public space but for a private physiological space-and empty organ. The materials used (gold, silver and stainless steel) were biocompatible and not reactive to the acidic contents of the stomach. The sculpture had to close into a capsule so it could be safely inserted down the oesophagus into the stomach. Not as a prosthetic implant but as an aesthetic addition. Not for some medical necessity but as an act of contingency. The body becomes not a site for the psyche, nor for social inscription but merely a site for an artwork. Once inside the stomach, there was a simple machine choreography with the sculpture opening and closing, extending and retracting, with a flashing light and a beeping sound. The performance occurred in a private clinic 5 minutes from a hospital, in case the stomach was accidently punctured.

As Justyna Szulich-Kałuża notes, already in the 19th century an outstanding, comprehensive German thinker-philosopher and sociologist Georg Simmel wrote-contributed to the recognition of the need for a holistic connection

\footnotetext{
${ }^{30}$ Droga do nieśmiertelności po przez [sic!] umaszynowienie ludzi. To sie już dzieje, http://globalne -archiwum.pl/droga-do-niesmiertelnosci-po-przez-umaszynowienie-ludzi-to-sie-juz-dzieje/ (accessed: 2.11.2019).

${ }^{31}$ Orlan, http://www.orlan.eu/ (accessed: 28.12.2019).

32 The series of performances Suspensions (1976-1988) Stelarc performer in various places and combinations, including being suspended on 25 ropes attached using old hooks driven into the human body.
} 
of the psyche with human physicality ${ }^{33}$. However, according to Stelarc, the body is experienced as hollow with no meaningful distinctions between public, private and physiological spaces. The hollow body becomes a host, not for a self but simply for a sculpture. As surface, skin was once the beginning of the world and simultaneously the boundary of the self. But now stretched, pierced and penetrated by technology, the skin is no longer the smooth and sensuous surface of a site or a screen. Skin no longer signifies closure. The rupture of surface and skin means the erasure of inner and outer. ${ }^{34}$ Another artist: Genesis Breyer P-Orridge, a Biritsh musician (Psychic TV, Throbbing Gristle) and performer (COUM Transmissions), one of the creators of the industrial trend, underwent a series of advanced plastic surgeries to become similar to his recently deceased partner, Lady Jaye; when she was alive, she modified her body herself following the example of Breyer P-Orridge. This intereference in the body, close to the ideas of transhumanism, was based on motivations far from progressive fetishism. Pandrogeny, postulated by the couple Breyer P-Orridge, was meant to be, apart from emotional unification, ultimate exposal of the constructs of identity, an act revealing 'real humanity.' 35

The above-quoted examples of the transfer of machine/technology into the body, which are a manifestation of transgression, support the assumption that crossing the boundaries of the body changes the body-machine/technology relationship. Although they are less invasive than the process of cyborgisation, undoubtedly they change the perception of the body. It is 'material,' 'fabric' used in more and more spectacular experiments, losing its sanctity, inviolability and dignity.

\section{FUNCTIONING OF THE BODY IN THE MACHINE \\ AS A CHALLENGE FOR TRANSHUMANISM}

Innovative technologies interfere with the human body in a more and more invasive way. DNA modifications, programming human behaviour, influencing the development of specific features at the expense of others,${ }^{36}$ apart from

\footnotetext{
${ }^{33}$ Justyna SzULICH-KAŁUŻA, Grzegorz WinNICKI, "Portretowe odsłony Leszka Mądzika — w poszukiwaniu malarskich inspiracji na fotoportretach artysty," in Artes Liberales. Teatr-Sztuka-Media, ed. Stanisław Fel, Justyna Szulich-Kałuża, Paweł Nowak, Małgorzata Sławek-Czochra (Lublin: Wydawnictwo KUL, 2018), 311.

${ }^{34}$ STELARC, Stomach Sculpture, http://stelarc.org/?catID=20349 (accessed: 28.12.2019).

${ }^{35}$ Olga DREnDA, "Maszyna i operator. Transhumanistyczna wizja ciała," Znak no. 4(2011): 674-675.

${ }^{36}$ Droga do nieśmiertelności, 1.
} 
the numerous positive applications, they are also an instrument for the implementation of the principles of transhumanism, and above all for the creation of the posthuman. ${ }^{37}$ Its primary features include: lack of the ageing process of the human body, resistance to diseases, improved and additional senses, ability to control one's own needs and emotions, unlimited intellectual capabilities. ${ }^{38}$

The premise of posthumanism and transhumanism is not the death of the human body in the literal sense but rather the birth of a new human, posthuman, superintelligence, created by uniting the human body with the machine. Transhumanists point at many technologies which can be used to improve the human body and to increase its abilities. By placing the body inside the machine, they aim to gain immortality or to show 'redundancy' and as such the deprivation of the natural human body. Molecular nanotechnology, nanomedicine, nanorobots, regenerative medicine are to enable people to take full control over biochemical reactions taking place in human bodies, including the elimination of the ageing process and diseases. Many transhumanists use prostheses, implants and the transplants of organs after they are worn out or damaged as well as plastic surgery making it possible to achieve appearance more attractive than natural.

In the scope of the improvement of the physical fitness of the human body, transhumanists postulate the exocortex: a hypothetical artificial organ which is an extension of the brain and which carries out some of its functions (e.g. additional memory) and the transfer of the mind (brain emulation). This is a hypothetical process of copying or transferring the mind from the biological brain of a human to a computer by precisely mapping all neural connections in the brain and faithfully recreating their activity in a computer simulation. 'Mind uploading' can be 'destructive' - the real (in contrast with the artificial one) brain is destroyed in the process and 'non-destructive' - the biological brain remains intact and co-exists with the uploaded copy. ${ }^{39}$ 'This mind

${ }^{37}$ Nick Bostrom et al., Transhumanistyczne FAQ (czyli transhumanistyczne pytania $i$ odpowie$d z i)$, http://www.transhumanism.org/index.php/WTA/more/659/ (accessed: 3.10.2019). Transhumanism can be understood in two ways. Firstly, as 'the study of the consequences, promises and potential threats resulting from the use of science, technology and other creative means aiming to overcome basic human limitations.' Secondly, as an 'intellectual-cultural movement, positively addressing the possibility, and the need, to fundamentally change the human condition, especially by using technology to eliminate the ageing process and to greatly improve the intellectual, physical and mental capabilities of the human.'

${ }^{38}$ Nick Bostrom, "In Defense of Posthuman Dignity,” Bioethics 19, no. 3(2005): 202-214.

${ }^{39}$ Cf. Vernor VINGE, The Coming Technological Singularity, https://edorap. sdsu.edu/ vinge/ misc/singularity.html (accessed: 13.10.2019). 
uploading could make it possible to create 'back-up copies of oneself' and the ability to 'transfer self' with the speed of light, which would lead to the possibility to use "the mind" to control one's "robot agent." ${ }_{40}$ In Hans Moravec's project entitled 'Transmigration,' which assumes the surgical transfer of human mental functions into computer software, the remaining human body and brain tissue will become useless 'meat.' Freeing the body from its biological limitations will enable humanity to enter the state of bodiless, mental existence, deprived of any limitations. ${ }^{41}$

One of the ways of machinising the human being and achieving immortality of the body is placing the human brain inside the machine/robot. At present there is intensive work on developing fully advanced cybernetic organisms. Among others, in Switzerland a group of scientists are trying to replicate the human brain, assembling it from individual neurons with the aim to building a complete virtual mind within ten years. In the United States, scientists from the Massachusetts Institute of Technology 'create a map of all the synapses in the brain, billions of connections among neurons in order to find the centre of human awareness. Their task will be to fill in an empty space in a machine with a scanned area of human consciousness," 42 that is transferring a human being, his consciousness into the machine/computer. Cybernetics, or the use of technology to modify the genetic code, gives the potential to restructure the system, to update it and thus to reprogram humanity forever, to remove the causes of ageing of the human body. ${ }^{43}$

He was the first to copy Martine Rothblatt's human mind. It should be noted that He copied but did not build the human biological brain. He only copied the mind of a human and placed it inside the machine Bina-48 (Breakthrough Intelligence via Neural Architecture) ${ }^{44}$ The machines got its looks and name to honour Martine's wife, Bina Aspen. A digital version of Bina Aspen was created 5 years ago - her consciousness (memories, thoughts and feelings) were written down in the form of a code and then Bina Aspen's digital consciousness was placed inside the robot Bina-48. The android can talk, answer questions and has spontaneous thoughts - it behaves like Bina Aspen. 'The brain' of the robot was developed to resemble the human one, including the

\footnotetext{
${ }^{40}$ Ibidem, 113.

${ }^{41}$ STARKOWSKI, "Technicyzacja ciała," 125-136.

${ }^{42}$ Droga do nieśmiertelności, 2.

${ }^{43}$ Ibidem.

${ }^{44}$ John MolL, Naukowcy skopiowali umyst człowieka i umieścili go w maszynie, https://tylko nauka.pl/wiadomosc/naukowcy-skopiowali-umysl-czlowieka-umiescili-go-w-maszynie (accessed: 11.10.2019).
} 
way of storing information, creating emotions and obtaining self-awareness. The robot brain resembles the human brain, but it is not a natural, biological brain.

\section{THE INTERNET OF BODIES/BRAINS?}

The third - not very probable - perspective of the body-machine system is the functioning of the human body, and more specifically of a brain fused with the internet. Carike Loretz predicts that after 2030 Internet Web 5.0 (Telepathic Web or Symbionet Web) will become widespread, within which brain implants make it possible for people to communicate with the internet via thoughts. Highly intelligent interactions between machines and people will develop. ${ }^{45}$ For over 30 years there has been intensive research into developing artificial intelligence, making computers compatible with human minds and also into producing devices cooperating with electric impulses sent by human brain and the central nervous system. ${ }^{46}$ The effect/result of cyborgization, apart from the possibility for people to use new prostheses, implants or the hypothetical exocortex (an artificial organ which is an extension of the brain and carries out some of its functions) - in the near future-it will be possible to directly connect the human brain to a computer (the brain-computer interface). Raymond Kurzweil-director of engineering in the Google Corporation and a proponent of transhumanism-predicts that it will soon be possible to inject nanorobots into the human blood-intelligent machines the size of blood cells which will form a wireless network in the brain connecting human neurons directly to the internet. ${ }^{47}$ From here it only takes one small step to have microscopic electrical-biological implants inserted into the human brain, which will integrate with them for good at the molecular and DNA levels and thus will integrate human brains, via terrestrial or satellite digital signal—into the global, cellular telecommunications GMS network and into the internet. The brain will simply become a biological computer, containing electronic controlling elements inside. Elon Musk, CEO of Neuralink, a company engaged in the development of neurotechnology, integration of the human brain

\footnotetext{
${ }^{45}$ Carike LORETZ, "The World Wide Web - from Web 1.0 to Web 5.0," https://carikesocial. wordpress.com/2017/03/15/the-world-wide-web-from-web-1-0-to-web-5-0/ (accessed: 2.05.2019).

${ }^{46}$ Znamie Bestii, prace nad cyborgizacja umaszynowieniem ludzi, http://globalne-archiwum. pl/znamie-bestii-i-prace-nad-cyborgizacja-umaszynowieniem-ludzi/ (accessed: 19.10.2019).

${ }^{47}$ Janusz MORBITZER, "Człowiek w świecie technologii informacyjnych,” in Edukacja artystyczna a rzeczywistość medialna, ed. Romualda Ławrowska, Bożena Muchacka (Kraków: Wydawnictwo Naukowe Uniwersytetu Pedagogicznego, 2009), 20.
} 
with artificial intelligence, already in 2021 is going to introduce onto the market devices that can be implanted into the human brain in order to facilitate people connecting with software. There improvements can augment memory or enable more direct communication with hardware, improve the quality of life of people suffering from diseases which make it impossible to communicate with surroundings in atypical way (e.g. patients with amyotrophic lateral sclerosis) and facilitate communication by controlling hardware solely by the use of thoughts. ${ }^{48}$

The integration of the human brain with the internet is to enable communication with any people and also the communication of the body with other bodies, which will gain new power in the virtual structure but will also face new threats. According to Stelarc 'the Internet becomes a system which switches and connects [bodies MG]. We may be developing such strategies where the internet becomes an external nervous system connecting bodies, which are nodes and links. ${ }^{49}$ Hence, questions arise: can the internet of bodies be developed/suggested in a similar fashion to the internet of things: are the attempts taken within hybridization and transhumanism going towards the internet of bodies?

A specific hybridization of the body and the machine, according to Stelarc, 'does not want to change the body into the machine but rather wants to make it compatible [...]. It is not the liberation of the body as such that is the challenge but spreading based on creating a network of bodies. What is most important is not what emanates from the body but rather what happens between bodies, ${ }^{50}$ following Stelarc's thought - what happens between brains connected to the global network. The hypothetical internet of the bodies, like the internet of things, could facilitate the transmission of information or communication. At the same time we should remember that within the global network, to which the brain would be connected, a human being of this type (a posthuman hybrid) can be easily controlled and monitored just like nowadays all machines and computers operating within a common network (for example in an office, plant or factory). ${ }^{51}$ 'There is a very high risk that by implanting a foreign electronic device into the human body, it will be possible to influence the person through the device, control their behaviour, thoughts, beliefs, simply totally enslave people and then as much of the civilization as

\footnotetext{
${ }^{48}$ Elon MuSK, „Elon Musk Biography,” https://www.biography.com/business-figure/elon-musk (accessed: 12.05.2019).

${ }^{49}$ BAKKE, Ciało otwarte, 154.

${ }^{50}$ Ibidem, 154-155.

${ }^{51}$ Znamię Bestii, 2.
} 
possible. We should talk and write about this because the reality of controlled humans is not only an idea but an approaching future. ${ }^{52}$

\section{CONCLUSION}

Scientific and technological progress is an ambivalent phenomenon itself. It is up to the decision of humans whether modern technologies/machines will be used to overcome several limitations of the body, within transgression and cyborgisation; or to create and carry out transhumanistic, utopic visions of a new human (posthuman) by overcoming genetic determinants of the human body and improving the functioning of the brain including a change in the nature of the human. Both transgressive actions and transhumanism can aim to machinise the human, determining the new body/machine relationship. The transfer of the machine into the human body - to various degrees - is assumed both by transgression and transhumanism. Moreover, the latter also aims at a reverse process-placing the body inside the machine. In both cases the boundary of the human body is crossed, although the results/consequences are different and not comparable. It is difficult to compare implants, prostheses or organ transplants with the technology of mind transfer and the internet of bodies.

Experimenting with the human body as part of transgressive activities, although it is connected with crossing the boundary between what is external and what is internal, in a lesser degree violates the boundary between the sacred and the profane. It includes less invasive technologies, allowing us to overcome individual abilities and limitations. The assumptions of transhumanism, trying to change the nature of humans, unquestionably cross the boundary between what is natural and what is artificial (that is technology); between what divides the sacred and the profane.

\section{BIBLIOGRAPHY}

Ascott, Roy. "Behaviourables and Futuribles." In Theories and Documents of Contemporary Art: A Sourcebook of Artists' Writings, edited by Kristine Stiles, Peter Howard Selz, 489-491. Berkely \& Los Angeles: University of California Press, 1996.

Ascott, Roy. "Consciousness reframed: Art and consciousness in the post-biological era." Digital Creativity 9, no. 1(1998): Computers \& Post-Biological Art: 5-6.

\footnotetext{
${ }^{52}$ Ibidem.
} 
Ascott, Roy. The architecture of cyberception. Stambut: Leonardo Electronic Almanac, 1994.

BAKKE, Monika. Ciało otwarte: filozoficzne reinterpretacje kulturowych wizji cielesności. Poznań: Wydawnictwo Naukowe UAM, 2000.

Bostrom, Nick et al. Transhumanistyczne FAQ (czyli transhumanistyczne pytania i odpowiedzi), http://www.transhumanism.org/index.php/WTA/more/659/ (accessed: 3.10.2019).

Bostrom, Nick. “In Defense of Posthuman Dignity.” Bioethics 19, no. 3(2005): 202-214.

Braidotti, Rosi. The Posthuman. Oxford: Polity Press, 2013.

Clynes, Manfred E. \& Nathan KLINE. “Cyborgs and Space.” Astronautics no. 8(1960): 29-33. https://pl. scribd.com/doc/2962194/Cyborgs-and-Space-Clynes-Kline?autodown=pdf (accessed: 3.10. 2019).

DERRIDA, Jacques. "Jednojęzyczność innego, czyli proteza oryginalna." Translated by Andrzej Siemek. Literatura na Świecie no. 11-12(328-329)(1998): 24-111.

DrendA, Olga. "Maszyna i operator. Transhumanistyczna wizja ciała.” Znak no. 4(2011): 674-675.

Droga do nieśmiertelności po przez [sic!] umaszynowienie ludzi. To sie już dzieje. http://globalne archiwum.pl/droga-do-niesmiertelnosci-po-przez-umaszynowienie-ludzi-to-sie-juz-dzieje/ (accessed: 2.11.2019).

FRANCKIEWICZ-OLCZAK, Izabela. "Body art—ciało, sztuka, technologia. Od ciała ułomnego do bezawaryjnego humanoida.” Przeglad Socjologii Jakościowej 8, no. 2(2012): 228-241.

GRUCHOŁA, Małgorzata. “'Wearable technology' wyznacznikiem transgresji czy regresu intelektualno-kulturowego? (na przykładzie transhumanizmu).” Spoleczeństwo i Rodzina 55, no. 2(2018): 50-65.

HARAWAY, Donna. "A cyborg manifesto: Science, technology, and socialist-feminism in the late twentieth century." In Simians, cyborgs and women: The reinvention of nature, 149-181. New York: Routledge, 1991.

KiLIAN, Edyta. "Roman Bromboszcz jako poeta-cyborg. Narzędzia i techniki współczesnego twórcy.” In Technokultura: transhumanizm i sztuka cyfrowa, edited by Damian Gałuszki, Grzegorz Ptaszek, Dorota Żuchowska-Skiba, 213-235. Kraków: Wydawnictwo Libron, 2016.

KNAPCZYK, Józef. Zarys robotyki. Nowy Sącz: Wydawnictwo Naukowe Państwowej Wyższej Szkoły Zawodowej w Nowym Sączu, 2015.

KozIELECKI, Józef. Społeczeństwo transgresyjne. Szansa i ryzyko. Warszawa: Wydawnictwo Akademickie „Żak”, 2004.

LORETZ, Carike. "The World Wide Web — from Web 1.0 to Web 5.0.” https://carikesocial.wordpress. com/2017/03/15/the-world-wide-web-from-web-1-0-to-web-5-0/ (accessed: 2.05.2019).

MoLL, John. Naukowcy skopiowali umysł człowieka i umieśsili go w maszynie. https://tylkonauka. $\mathrm{pl} /$ wiadomosc/naukowcy-skopiowali-umysl-czlowieka-umiescili-go-w-maszynie (accessed: 11.10.2019).

Moravec, Hans. Mind Children: The Future of Robot and Human Intelligence. Cambridge, Mass: Harvard University Press, 1988

MorbitZer, Janusz. “Człowiek w świecie technologii informacyjnych.” In Edukacja artystyczna a rzeczywistość medialna, edited by Romualda Lawrowska, Bożena Muchacka, 20-34. Kraków: Wydawnictwo Naukowe Uniwersytetu Pedagogicznego, 2009.

MUSHIAKI, Shigeru. "Neuroscience and nanotechnologies in Japan - beyond the hope and hype of converging technologies." International Journal of Bioethics 22, no. 1(2011): 91-97.

Musk, Elon. "Elon Musk Biography.” https://www.biography.com/business-figure/elon-musk (accessed: 12.05.2019). 
OGONOWSKA, Agnieszka. "Ubiór jednostki jako przedmiot interpretacji i badań interdyscyplinarnych”. In Komunikacja wizualna, edited by Piotr Francuz, 229-243. Warszawa: Wydawnictwo Naukowe Scholar, 2012

Orlan. http://www.orlan.eu/ (accessed: 28.12.2019).

PAlese, Emma. "Robots and cyborgs: to be or to have a body?" Poiesis \& Praxi 8, no. 4(2012): 191-196.

Prof. Roy Ascott (Wielka Brytania). http://www.poznan.pl/mim/main/prof-roy-ascott-wielkabrytania,p,12973,23787,23930.html (accessed: 07.10.2019).

Roco, Mihail C. \& William S. BAINBRIDGe. "Overview Converging Technologies for Improving Human Performance.” In Converging Technologies for Improving Human Performance, edited by Mihail C. Roco \& William S. Bainbridge, 1-27. Dordrecht: Kluwer Academic Publishers currently Springer, 2004.

SAROwSKI, Łukasz. "Robot społeczny - wprowadzenie do zagadnienia." Roczniki Kulturoznawcze 8, no. 1(2017): 75-89.

ŠMID, Wacław. Leksykon komunikacji medialnej. Kraków: Dr Lex, 2010.

SPRINGER, Claudia. Electronic Eros. Bodies and Desire in the Postindustrial Age. Texas: University of Texas Press, 1996.

STARKowSKI, Maciej. “Technicyzacja ciała. Pytanie o człowieka.” In Umyst-Ciało-Sieć, edited by Edyta Stawowczyk-Tsalawoura, Wojciech Chyła, 125-136. Poznań: Wydawnictwo Naukowe UAM, 2005.

Stelarc. http://stelarc.org/projectp.php (accessed: 3.10.2019).

STELARC. Stomach Sculpture. http://stelarc.org/?catID=20349 (accessed: 28.12.2019).

SzULICH-KAŁUŻA, Justyna \& Grzegorz WinNICKI. "Portretowe odsłony Leszka Mądzika-w poszukiwaniu malarskich inspiracji na fotoportretach artysty." In Artes Liberales. Teatr-SztukaMedia, edited by Stanisław Fel, Justyna Szulich-Kałuża, Paweł Nowak, Małgorzata Sławek-Czochra, 305-322. Lublin: Wydawnictwo KUL, 2018.

VINGE, Vernor. The Coming Technological Singularity. https://edorap.sdsu.edu/ vinge/misc/singula rity.html (accessed: 13.10.2019).

Znamię Bestii, prace nad cyborgizacją umaszynowieniem ludzi. http://globalne-archiwum.pl/znamiebestii-i-prace-nad-cyborgizacja-umaszynowieniem-ludzi/ (accessed: 19.10.2019).

\section{MASZYNA W CIELE - CIAŁO W MASZYNIE: POSTRZEGANIE CIAŁA LUDZKIEGO W SPOŁECZEŃSTWIE POSTBIOLOGICZNYM}

\section{Streszczenie}

Celem artykułu była krytyczna analiza relacji ciało-maszyna w społeczeństwie postbiologicznym, w ujęciu Roya Ascotta z dwóch perspektyw (David Tomas): z jednej strony funkcjonowanie maszyny w ciele jako przejaw transgresji, $\mathrm{z}$ drugiej - funkcjonowanie ciała w maszynie jako wyzwanie transhumanizmu. Przyjęto pytanie badawcze: jaki obraz ciała proponuje i narzuca społeczeństwo postbiologiczne? Jak maszyna cybernetyczna funkcjonuje wewnątrz ciała ludzkiego oraz jak ciało funkcjonuje w maszynie? Czy podejmowane próby w ramach transhumanizmu nie zmierzają w kierunku internetu ciał? Przyjęto hipotezę, że przekraczanie kolejnych granic ciała w ramach transgresji 
i transhumanizmu zmienia relację ciało-maszyna. Artykuł ma charakter konceptualny oraz analityczno-opisowy. Hipoteza została potwierdzona.

Słowa kluczowe: cyborgizacja; maszyna cybernetyczna; ciało ludzkie; społeczeństwo postbiologiczne; relacja ciało-maszyna; transgresja; transhumanizm.

\author{
THE MACHINE IN THE BODY - THE BODY IN THE MACHINE: \\ PERCEPTION OF THE HUMAN BODY IN A POST-BIOLOGICAL SOCIETY
}

\title{
Summary
}

The aim of the article is to provide a critical analysis of the body-machine relationship in the context of post-biological society (as viewed by Roy Ascott) from two perspectives (David Tomas): on the one hand the functioning of the machine in the body as a manifestation of transgression and on the other one - the functioning of the body in the machine as a challenge and assumption of transhumanism. The term 'machine' in this article is limited to the cybernetic machine. This article is limited to a critical analysis of a new type of person: a cyborg - a hybrid of a human being and a machine in a post-biological society.

The following research question has been formulated: what image of the body is suggested, imposed, or maybe enforced by a post-biological society? How does the body function and influences the machine (the body inside the machine), how does the machine influence the body (the machine inside the body) and finally - how do these relationships relate to the broader social context? Are the attempts within hybridization and transhumanism not leading to the internet of bodies? Can an internet of bodies be developed just like the internet of things? The article accepts the hypothesis that crossing subsequent boundaries of the human body in a post-biological society changes the body-machine relationship. The nature of the article is analytical-descriptive and conceptual. The thesis has been confirmed.

Key words: cyborgisation; cybernetic machine; human body; post-biological society; the body-machine relationship; transgression; transhumanism. 